\title{
Screening Selected Solanum Plants as Potential Rootstocks for the Management of Root-Knot Nematodes (Meloidogyne incognita)
}

\author{
Benjamin A. Okorley (D), Charles Agyeman (D, Naalamle Amissah, and Seloame T. Nyaku (iD \\ Department of Crop Science, University of Ghana, P.O. Box LG 44, Legon-Accra, Ghana \\ Correspondence should be addressed to Seloame T. Nyaku; seloame.nyaku@gmail.com
}

Received 15 May 2018; Revised 3 July 2018; Accepted 30 July 2018; Published 25 September 2018

Academic Editor: Maria Serrano

Copyright ( 2018 Benjamin A. Okorley et al. This is an open access article distributed under the Creative Commons Attribution License, which permits unrestricted use, distribution, and reproduction in any medium, provided the original work is properly cited.

\begin{abstract}
Root-knot nematodes (RKNs) (Meloidogyne spp.) represent agricultural pest of many economic crops, including tomatoes and potatoes. They advance a complex parasitic relationship with roots of tomato plants leading to modification of host structural and physiological functions in addition to significant yield loss. Resistance in solanaceous plants to RKNs has been identified and associated with the possession of Mi gene. The reaction of four Solanum rootstocks (S. aethiopicum L., S. macrocarpon L., S. lycopersicum L."Mongal F1," and S. lycopersicum L. "Samrudhi F1") was evaluated in pots and in a natural Meloidogyne spp.-infested field in a two-year trial (2015-2016), to identify RKN-resistant rootstock(s), which can be utilized in tomato grafting as a management measure against these nematodes. A rootstock's reaction to RKNs was assessed using root gall scores (GSs), egg count/g of root, and reproductive factors (Rfs) at the end of 6 and 12 weeks after transplanting (wat) in infested fields, respectively. Solanum macrocarpon, S. aethiopicum, and Mongal F1 showed tolerant responses with reduced root galling and low to high reproductive factors in pot and field experimentation. Although Samrudhi F1 was resistant in both pot and field trials and consistently decreased nematode root galling $(<1.00)$ and reproduction $(\mathrm{Rf}<1.00)$, it failed to significantly increase yield, as compared with the highest yield obtained by the tolerant rootstock, Mongal F1 (870.3 and $1236.6 \mathrm{~g} /$ plant, respectively). Evaluation of the four rootstocks against four $(0,500,1,000$, and 5000) RKN inocula levels (Juveniles) showed no significant differences among the growth parameters (fresh and dry shoot and root weights). Root-knot nematode-susceptible tomato varieties, for example, Pectomech F1, a popular tomato variety in Ghana, can be grafted onto the RKN-resistant and RKN-tolerant rootstocks for increased yields.
\end{abstract}

\section{Introduction}

Tomato (Solanum lycopersicum L.) is an annual crop of the Solanaceae family, and the second most widely consumed vegetable after potatoes [1]. Tomato fruits are highly nutritious, and constitute a rich source of vitamins $\mathrm{A}, \mathrm{C}$, and $\mathrm{E}$, and essential minerals, namely, potassium, phosphorus calcium, magnesium, and iron [2, 3]. Tomato and its products contain the antioxidant lycopene, which reduces cancers and development of atherosclerosis $[4,5]$. The large diversity in the crop makes it adaptable to different climatic conditions, ranging from temperate to tropical environments, production methods, and uses [6]. Ghana has a young tomato industry (production estimated at 366, 722 tonnes from 47,000 hectares of land [7]), with the potential to increase production in the savannah and transitional zones because of the derived income and nutritional benefits. Pectomech F1, Power Rano, and "Wosowoso" are popular varieties cultivated for high yield and quality fruits. However, domestic production levels over the years have been low, mainly due to its vulnerability to pest and diseases, including plant-parasitic nematodes [8].

Plant-parasitic nematodes are economic pests of agriculture worldwide, with more than 3000 plants species as host [9-11]. Global losses associated to root-knot nematodes (RKNs) alone from 75 countries as at 2000 was valued at $\$ 121$ billion [12] and cost about $\$ 500$ million for their annual control $[13,14]$. In Ghana, RKNs are responsible for $33 \%$ of vegetable losses per season [15], in which $73-100 \%$ are realized in tomato production alone [16]. The RKNs thus impact a key limitation to tomato production, as the crop is considered the most vulnerable in the tropics $[17,18]$. 
Currently, crop rotation, soil solarization, nematode-free seedlings, and the use of nematicides are adopted by Ghanaian farmers for managing nematodes $[16,19]$. The withdrawal of extensively used fumigants such as ethylene dibromide, because of its carcinogenic nature and its ability to contaminate groundwater $[12,20]$, has necessitated the adoption and worldwide use of tolerant/resistant rootstocks, as an alternative for nematode control because they are safe to both farmers and the environment [21].

Nematode-resistant plants or rootstocks have the intrinsic ability, to be unaffected significantly upon nematode attack, and will greatly contribute to reducing nematode infestations in tomato fields [22-24]. Grafting utilizing resistant rootstocks has proven to effectively manage RKNs and improve yield in tomato and eggplant cultivated in naturally infested nematode soils [25]. Resistance to RKN species ( $M$. incognita, $M$. javanica, and $M$. arenaria) is conferred by a single dominant $M i$ gene, introduced from the wild relative S. peruvianum accession (P.I. 128657), through embryo rescue technique, into commercially cultivated tomatoes [26, 27]. Dhivya et al. [28] reported resistant and susceptible reaction, in wild Solanum plants after assessing their response to RKN. In another study, 33 tomato genotypes were evaluated against $\mathrm{RKN}$, and variable responses in gall development and nematode reproduction existed [29]. Plants with the $M i$ gene also effectively increased yields to about ten-fold, compared with susceptible plants at high nematode inoculum levels of about 200, 000 eggs/plant [24]. Solanaceous plants, for example, $S$. aethiopicum, S. macrocarpon, S. torvum, and S. lycopersicum cultivars, are commercially available, and common among local farmer seed stocks in Ghana. However, the use of resistant rootstocks in tomato cultivation remains less explored, due to the unknown response of this Solanum spp. to RKNs. Grafting of tomato scions with superior traits onto RKN-resistant rootstocks will help manage this biotic stress in a healthy and environmentally friendly manner [30], reduce production cost, and improve yields [31].

The use of resistant Solanum plants in grafting experiments in Ghana is in its infancy; therefore, there is a need to identify sources of resistance in the available Solanum rootstocks for managing the $\mathrm{RKN}$ problem in tomato fields. This study was thus initiated to screen and identify potential rootstock(s) among four selected Solanum plants for resistance to $M$. incognita.

\section{Materials and Methods}

2.1. Plant Materials. Seeds of the test rootstocks, $S$. aethiopicum and S. macrocarpon "Gboma," were obtained from the Department of Crop Science, University of Ghana. Solanum lycopersicum "Mongal F1" and S. lycopersicum "Samrudhi F1" were supplied by Agriseed Company and East-West Seed Ltd., respectively.

2.2. Sowing of Rootstock Seeds. The seeds were sown in trays containing oven-sterilized soil. Solanum macrocarpon and S. aethiopicum were sown ten days earlier than the other tomato rootstocks because of their slow growth rate. A week after seedling emergence, N-P-K: 15-15-15 (6g/L) nutrient solution was applied once every week by immersing in a bath for 5-6 minutes. A shade cover was placed over the seedlings to minimize the solar radiation on the leaves. Suncozeb 80 WP at $20 \mathrm{~g} / \mathrm{L}$ of $\mathrm{H}_{2} \mathrm{O}$ was sprayed, until runoff close to the crown of the seedlings, to prevent damping-off on seedlings. Two weeks before transplanting the seedling, the shade cover was completely removed to allow them harden-off.

2.3. Experimental Area (Field Trials). The field experiments were conducted at the Biotechnology and Nuclear Agricultural Research Institute (BNARI) of Ghana Atomic Energy Commission, Legon-Accra on a natural RKN-infested field. The experimental site had a sandy loam soil, humid tropical climate with average low-high day temperatures of $25-34^{\circ} \mathrm{C}$ (dry season) and $25-29^{\circ} \mathrm{C}$ (rainy season), $\mathrm{pH} \approx 6.4$, and a history of being used continuously for growing vegetables, thus making the site a hot spot for RKNs. Laboratory and nursery activities were carried out in the Department of Crop Science, University of Ghana.

2.4. Experimental Design (Field Trials). The experimental field was slashed and debris collected; then, three beds each measuring $23.2 \mathrm{~m} \times 2.0 \mathrm{~m}$ were raised and pegged at a planting distance of $80 \mathrm{~cm} \times 40 \mathrm{~cm}$. A randomized complete block design (RCBD) with three replicates partitioned by two alleys of $0.5 \mathrm{~m}$ each was used. A block contained five plots, each measuring $4.0 \mathrm{~m} \times 1.6 \mathrm{~m}$. Thirty (30) plants constituted a plot, with ten plants in a row and three plants between rows. Eight middle row plants were used as record plants, from which data were taken. The experimental setup was repeated for the succeeding trial in 2016. The layout for the pot experiments was a $4 \times 4$ factorial, arranged in a split plot design with three replicates.

\subsection{Agronomic Practices and Parameters Taken on Tomato} Plants (Field Trials). Four-week-old seedlings were transplanted (one per stand), and a starter solution (N-P-K: 15$15-15$ at $6 \mathrm{~g} / \mathrm{L}$ of water) applied at $100 \mathrm{~mL} /$ plant. Two (2) $\mathrm{kg}$ N.P.K was mixed with $1 \mathrm{~kg} \mathrm{NH}$ and was also applied at $15 \mathrm{~g} /$ plant as a side dressing. Agricombi (fenitrothion 30\% + fenvalerate $10 \%$ ) were sprayed twice, at a rate of $50 \mathrm{~mL} / \mathrm{L}$ of $\mathrm{H}_{2} \mathrm{O}$, to control whiteflies, aphids, and red spider mites. The plants were cared for by regular watering and weed control. Plant height, plant girth, and chlorophyll contents were taken 5,7 , and 9 weeks after seedling transplant.

2.6. Experimental Design (Pot Trials). The layout for the pot experiment was a $4 \times 4$ factorial experiment, with a control arranged in a split plot design with three replicates, each experimental plot consisting of 30 plants. Root-knot nematode inoculums (Juveniles) were prepared by extracting nematode eggs from the roots of infested plants, and hatched into juveniles [32]. These were then concentrated into the various $\mathrm{RKN}$ inoculum levels $(0,500,1,000$, and 5,000). The plants (rootstocks) were then inoculated with the juveniles, 
by making a small hole or depression in the soil, at the base plants after which the required inoculum level was gently poured into the hole and covered.

2.7. Nematode Analysis. Soil samples taken from each plot were used to determine the RKN populations, before transplanting (initial nematode population $\mathrm{Pi}$ ), six weeks after transplanting (P6), and after harvesting (Pf) in each trial. Six random soil samples per plot were taken with a soil augur, and bulked together into a well-labeled plastic bag. A subsample of 200 cubic centimeter (cc) was used in soil extraction, through the sieving and sucrose centrifugation method [33]. Reproductive factors (Rfs) for each treatment plot, which is a ratio of the final to initial population $(\mathrm{Pf} / \mathrm{Pi})$, were used to determine the rate of nematode multiplication in the soil. Gall scoring and nematode egg extraction were carried out 6 and 12 weeks after transplanting rootstocks, to estimate RKN gall development and egg production on the host. Sampled roots were washed separately and air-dried for 5 minutes. Galls on each root system were scored on a scale of $0-10$ (no damage to severe damage), using the severity rating chart by Bridge and Page [34]. Roots were then cut into pieces, and nematode eggs extracted using $10 \%$ sodium hypochlorite $(\mathrm{NaClO})$ [32]. Eggs obtained were counted under the compound microscope (Exacta-OptechBiostar B5P, Germany) (magnification x100) and recorded. The mean gall scores (GSs), egg count per gram of root, and reproductive factors (Rfs) obtained from the two field trials were used as the basis to evaluate the resistance status of the rootstocks. Rootstocks were classified as resistant when their root $\mathrm{GS}<2$ and $\mathrm{Rf}<1$, tolerant when $\mathrm{GS}<2$ and $\mathrm{Rf} \geq 1$, or susceptible when $G S \geq 2$ and $\mathrm{Rf}>1[35,36]$.

2.8. Statistical Analysis. Data collected on agronomic parameters (plant height and plant girth), chlorophyll content, yield parameters, and plant biomass content were subjected to analysis of variance (ANOVA), using Genstat 12th edition software [37], and significant means separated, using least significant difference (LSD) at 5\%. Where necessary, data were transformed using the equation $\log (x+1)$, for normality.

\section{Results}

3.1. Root-Knot Nematode Gall Development, Egg Formation, and Reproduction among Selected Rootstocks Six and 12 Weeks after Transplanting Rootstocks. Four Solanum rootstocks were evaluated for resistance to RKNs in a naturally infested field, in two consecutive trials (dry season of 2015 and rainy season of 2016). Data on the RKN gall development and reproduction among the rootstocks for the two-year trial were highly comparable. Six weeks after transplanting the rootstocks, lower gall scores ranging from 0.33 to 0.67 were observed on S. macrocarpon, Samrudhi F1, and Mongal F1 (Table 1). In year 2, S. macrocarpon had the least root gall score (0.00), with a slight increase for Samrudhi F1 (0.17) compared with the others $(>0.50)$, six weeks after transplanting the rootstocks. Significant differences were absent among the rootstocks for eggs/g of root, six weeks after transplanting in both years; however, differences were observed among the eggs numbers twelve weeks after transplanting in both years. The recovered number of eggs/g of root ranged from 2 to 14,714 in Samrudhi F1 and $S$. aethiopicum, six and twelve weeks after transplanting the rootstock seedlings for year 1 . In year 2, however, eggs/g of root ranged from 20 to 11,280 in Samrudhi F1 and $S$. aethiopicum, six and twelve weeks after transplanting the rootstock seedlings. Nematode reproductive factors (Rfs) on the various rootstocks also ranged from 0.07 to 1.57 for Mongal F1 and S. aethiopicum, 6 and 12 weeks after rootstock transplant, respectively, in year 1 . In year 2 , however, Rf ranged from 0.45 to 2.37 for Samrudhi F1 and $S$. aethiopicum six and twelve weeks after rootstock transplant, respectively.

Within the pot experiments, significant differences did not exist among the rootstocks in relation to the various RKN inocula levels (500, 1000, and 5000), for mean gall scores and egg counts six weeks after treatment application (Table 2). However, significant differences were noted for mean gall scores and egg counts, twelve weeks after treatment application. The RFs for all rootstocks were below 1 .

There were no significant differences among the various plant growth parameters for weeks 6 and 12, among the rootstocks for the four RKN inocula levels applied (Table 3). Generally, dry shoot and root weights were lower compared with the fresh shoot and root weights.

\subsection{Mean Plant Height, Plant Girth, and Chlorophyll Contents} in Rootstocks to Root-Knot Infection Five, Seven, and Nine Weeks after Transplanting Rootstocks. Growth performances varied greatly among the rootstocks and between the dry and wet season trials. Significant increases $(P \leq 0.05)$ in plant height, girth, and chlorophyll contents were recorded for $S$. aethiopicum during the dry season (Figures $1(\mathrm{a} 1), 1(\mathrm{~b} 1)$, and $1(\mathrm{c} 1)$ ). Conversely, the vegetative growth of the three tomato rootstocks were robust in the rainy season, relative to $S$. aethiopicum and S. macrocarpon, but began diminishing during fruiting or after the seventh week (Figures 1(a2), 1(b2), and 1(c2)). Aside having the thickest stem, S. macrocarpon's chlorophyll content was also significantly increased $(P \leq 0.05)$, compared with the other rootstocks screened against RKNs (Figure 1(c2)).

3.3. RKN Infestation on the Different Rootstocks Yield Parameters. Overall, S. macrocarpon and S. aethiopicum showed significantly $(P \leq 0.05)$ increased number of fruits (10 and $12 /$ plant) and high yield performances $(227.50 \mathrm{~g}$ and $147.61 \mathrm{~g} /$ plant, respectively) in the dry season (year 1). Higher fruit yields were obtained for the three tomato rootstocks in the rainy season (year 2). The number of fruits/plant increased significantly $(P \leq 0.05)$, in both Mongal F1 (20) and S. aethiopicum (19). Fruit yield/plant for Mongal F1 $(1236.60 \mathrm{~g})$ greatly increased $(P \leq 0.05)$ relative to other three rootstocks screened against RKNs. Furthermore, the weight of individual fruits/plant for Samrudhi F1 
TABLE 1: Initial and final nematode count, mean gall scores, egg count/g of root, and reproductive factors (RFs) of RKNs after 6 and 12 weeks of transplanting rootstocks in 2015 (year 1) and 2016 (year 2) for field experiments.

\begin{tabular}{|c|c|c|c|c|c|c|c|c|c|c|}
\hline \multirow{2}{*}{$\begin{array}{l}\text { Treatment } \\
\text { Weeks }\end{array}$} & \multicolumn{3}{|c|}{$\begin{array}{l}\text { Nematode } \\
\text { count } / 200 \\
\mathrm{~cm}^{3} \text { of soil }\end{array}$} & \multicolumn{2}{|c|}{$\begin{array}{c}\text { Mean gall } \\
\text { scores }(0-10)\end{array}$} & \multicolumn{2}{|c|}{$\begin{array}{c}\text { Egg count/gram } \\
\text { of root } \\
\text { (transformed)* }^{*}\end{array}$} & \multicolumn{2}{|c|}{$\begin{array}{l}\text { Reproductive } \\
\text { factor }(\mathrm{Pf} / \mathrm{Pi})\end{array}$} & \multirow[t]{2}{*}{${ }^{\mathrm{y}}$ Reaction } \\
\hline & $\begin{array}{l}\text { Initial } \\
(\mathrm{Pi})\end{array}$ & $\begin{array}{l}\text { Six } \\
\text { (Pf) }\end{array}$ & $\begin{array}{l}\text { Twelve } \\
\text { (Pf) }\end{array}$ & Six & Twelve & Six & Twelve & Six & Twelve & \\
\hline \multicolumn{11}{|c|}{ Year 1 (dry season) } \\
\hline Sam & 133.00 & 85.33 & 48.67 & $0.50^{\mathrm{a} *}$ & $0.33^{\mathrm{a}}$ & $16.30(1.06)^{\mathrm{a}}$ & $54.33(1.23)^{\mathrm{a}}$ & 0.64 & 0.36 & $\mathrm{R}$ \\
\hline Mon & 839.33 & 59.67 & 99.00 & $0.67^{\mathrm{a}}$ & $3.00^{\mathrm{ab}}$ & $14.30(0.90)^{\mathrm{a}}$ & $1047.67(2.33)^{\mathrm{ab}}$ & 0.07 & 0.12 & $\mathrm{~T}$ \\
\hline S. M & 197.67 .00 & 46.67 & 24.00 & $0.33^{\mathrm{a}}$ & $0.67^{\mathrm{a}}$ & $2.00(0.43)^{\mathrm{a}}$ & $1438.33(3.06)^{b c}$ & 0.24 & 0.12 & $\mathrm{~T}$ \\
\hline S. A & 255.33 & 112.67 & 400.00 & $1.67^{\mathrm{a}}$ & $5.17^{\mathrm{b}}$ & $17.00(0.86)^{\mathrm{a}}$ & $14714.00(4.07)^{\mathrm{C}}$ & 0.44 & 1.57 & $\mathrm{~T}$ \\
\hline \multicolumn{11}{|c|}{ Year 2 (rainy season) } \\
\hline Sam & 397.00 & 178.00 & 227.00 & 0.17 & 0.67 & $20.00^{\mathrm{a}}$ & $900.00(2.66)^{\mathrm{a}}$ & 0.45 & 0.57 & $\mathrm{R}$ \\
\hline Mon & 220.00 & 176.00 & 331.00 & 0.50 & 1.67 & $50.00^{\mathrm{a}}$ & $5145.00(3.68)^{\mathrm{b}}$ & 0.80 & 1.50 & $\mathrm{~T}$ \\
\hline S. M & 472.00 & 244.00 & 515.00 & 0.00 & 1.33 & $33.00^{\mathrm{a}}$ & $4267.00(3.58)^{\mathrm{b}}$ & 0.52 & 1.09 & $\mathrm{~T}$ \\
\hline S. A & 239.00 & 286.00 & 567.00 & 0.50 & 2.17 & $48.00^{\mathrm{a}}$ & $11280.00(3.91)^{c}$ & 1.20 & 2.37 & $\mathrm{~T}$ \\
\hline
\end{tabular}

Gall scores: $0=$ no knots on roots; $10=$ all roots severely knotted, plant usually dead; rootstocks: Sam =Samrudhi F1; Mon = Mongal F1; S. M=S. macrocarpon; $\mathrm{S}$. A $=$ S. aethiopicum. ${ }^{\mathrm{y}}$ Reaction of rootstocks derived from 6 to 12 weeks after transplanting rootstocks $(\mathrm{R}=$ resistance and $\mathrm{T}=$ tolerance $) .{ }^{*} \mathrm{Means}$ having different letters in a column differed significantly $(P \leq 0.05) .{ }^{*} \log (x+1)$ transformed.

TABLE 2: Response of four rootstocks to four RKN inoculum levels on gall scores, egg count per gram of root, and reproductive factors 6 and 12 weeks after inoculation in pot experiments.

\begin{tabular}{|c|c|c|c|c|c|c|c|c|c|c|}
\hline \multirow[t]{2}{*}{ Rootstocks } & \multirow[t]{2}{*}{ Initial inoculum } & \multicolumn{2}{|c|}{$\begin{array}{l}\text { Mean gall score } \\
\qquad(1-10)\end{array}$} & \multicolumn{2}{|c|}{$\begin{array}{l}\text { Nematode count } \\
\text { per } 200 \mathrm{cc} \text { of soil } \\
\text { (Pf) }\end{array}$} & \multicolumn{2}{|c|}{$\begin{array}{c}\text { Egg count per gram } \\
\text { of root }\end{array}$} & \multicolumn{2}{|c|}{$\begin{array}{l}\text { Reproductive factor } \\
\qquad(\mathrm{Pi} / \mathrm{Pf})\end{array}$} & \multirow[t]{2}{*}{ Reaction } \\
\hline & & 6 weeks & 12 weeks & 6 weeks & 12 weeks & 6 weeks & 12 weeks & 6 weeks & 12 weeks & \\
\hline Mon & 500 & $0.51^{\mathrm{a} *}$ & $0.00^{\mathrm{a}}$ & 48.30 & 41.28 & $6.50^{\mathrm{a}}$ & $5.94^{\mathrm{a}}$ & 0.09 & 0.08 & $\mathrm{~T}$ \\
\hline SA & 500 & $0.22^{\mathrm{a}}$ & $0.20^{\mathrm{ab}}$ & 125.60 & 60.72 & $9.60^{\mathrm{a}}$ & $5.11^{\mathrm{a}}$ & 0.25 & 0.12 & $\mathrm{~T}$ \\
\hline Sam & 500 & $0.02^{\mathrm{a}}$ & $0.10^{\mathrm{a}}$ & 46.60 & 4.00 & $2.60^{\mathrm{a}}$ & $5.44^{\mathrm{a}}$ & 0.09 & 0.22 & $\mathrm{R}$ \\
\hline SM & 500 & $0.38^{\mathrm{a}}$ & $0.00^{\mathrm{a}}$ & 107.90 & 108.56 & $9.60^{\mathrm{a}}$ & $3.00^{\mathrm{a}}$ & 0.22 & 0.01 & $\mathrm{~T}$ \\
\hline Mon & 1000 & $1.11^{\mathrm{a}}$ & $0.10^{\mathrm{a}}$ & 62.20 & 20.56 & $12.8^{\mathrm{a}}$ & $3.89^{\mathrm{a}}$ & 0.06 & 0.02 & $\mathrm{~T}$ \\
\hline SA & 1000 & $0.67^{\mathrm{a}}$ & $0.00^{\mathrm{a}}$ & 192.30 & 93.89 & $12.2^{\mathrm{a}}$ & $8.56^{\mathrm{b}}$ & 0.19 & 0.09 & $\mathrm{~T}$ \\
\hline Sam & 1000 & $0.50^{\mathrm{a}}$ & $0.00^{\mathrm{a}}$ & 124.30 & 2.16 & $7.00^{\mathrm{a}}$ & $0.15^{\mathrm{c}}$ & 0.09 & 0.11 & $\mathrm{R}$ \\
\hline SM & 1000 & $0.44^{\mathrm{a}}$ & $0.00^{\mathrm{a}}$ & 86.10 & 108.44 & $15.3^{\mathrm{a}}$ & $6.33^{\mathrm{a}}$ & 0.12 & 0.00 & $\mathrm{~T}$ \\
\hline Mon & 5000 & $0.33^{\mathrm{a}}$ & $0.70^{\mathrm{c}}$ & 91.60 & 9.39 & $7.20^{\mathrm{a}}$ & $4.33^{\mathrm{a}}$ & 0.02 & 0.00 & $\mathrm{~T}$ \\
\hline SA & 5000 & $0.72^{\mathrm{a}}$ & $0.20^{\mathrm{ab}}$ & 158.40 & 90.33 & $11.9^{\mathrm{a}}$ & $5.00^{\mathrm{a}}$ & 0.03 & 0.02 & $\mathrm{~T}$ \\
\hline Sam & 5000 & $1.00^{\mathrm{a}}$ & $0.10^{\mathrm{a}}$ & 84.70 & 13.66 & $8.50^{\mathrm{a}}$ & $6.33^{\mathrm{a}}$ & 0.04 & 0.01 & $\mathrm{R}$ \\
\hline SM & 5000 & $0.55^{\mathrm{a}}$ & $0.00^{\mathrm{a}}$ & 206.00 & 71.00 & $9.60^{\mathrm{a}}$ & $1.15^{\mathrm{c}}$ & 0.02 & 0.00 & $\mathrm{~T}$ \\
\hline
\end{tabular}

Sam = Solanum lycopersicum "Samrudhi F1," Mon=Solanum lycopersicum "Mongal F1," SM=Solanum macrocarpon, and SA = Solanum aethiopicum $\left(\mathrm{R}=\right.$ resistance and $\mathrm{T}=$ tolerance). ${ }^{*}$ Means having different letters in a column differed significantly $(P \leq 0.05)$.

(66.95 g) was on the average heavier compared with the other rootstocks (Table 4 ).

\subsection{Effects of Root-Knot Nematode Infestation on Fresh and} Dry Weights of Shoot and Roots of the Rootstocks. Twelve weeks after transplanting, S. aethiopicum and S. macrocarpon accumulated significant $(P \leq 0.05)$ amounts of plant biomass, with respect to its fresh shoot $(331.40 \mathrm{~g}$ and $159.10 \mathrm{~g}$ ), and root weight (39.72 $\mathrm{g}$ and $14.05 \mathrm{~g}$ ), obtained in the dry season trial (Table 5). In the subsequent trial, however, the tomato rootstocks picked up steadily the fresh shoot weight of S. macrocarpon (357.39 g) and Mongal F1 $(325.28 \mathrm{~g})$, which were significantly increased $(P \leq 0.05)$, compared with the other rootstocks (Table 5). Significant differences also existed among the dry shoot and root weights for both year trials, and S. aethiopicum produced the highest dry weights (16.81 $\mathrm{g}$ and $19.43 \mathrm{~g}$ ) for years 1 and 2, respectively.

\section{Discussion}

The reproductive factors ( $\mathrm{Rfs}$ ) of the various rootstocks together with their mean gall scores (GS) provided an estimate of host suitability, to support nematode reproduction and were used to verify host resistance [38]. A rootstock's reaction to $\mathrm{RKN}$ resulting to $\mathrm{GS}<2$ and $\mathrm{Rf}<1, \mathrm{GS}<2$ and $\mathrm{Rf} \geq 1$, and $\mathrm{GS} \geq 2$ and $\mathrm{Rf}>1$ was identified as resistant, tolerant, and susceptible, respectively [35].

There is evidence to show that fecundity increases in more vulnerable plant hosts than in resistant or tolerant hosts [39]. Sobczak et al. [40] also described a stalled response of the tomato Hero-gene, against invading cyst 
TABLE 3: Fresh and dry shoot and root weights in four rootstocks to three RKN inocula levels $(0,500,1000$, and 5000$) 6$ and 12 weeks after treatment application.

\begin{tabular}{|c|c|c|c|c|c|c|c|c|c|}
\hline Rootstocks & $\begin{array}{l}\text { Initial RKN } \\
\text { inocula levels }\end{array}$ & $\begin{array}{l}\text { Fresh root } \\
\text { weight }(\mathrm{g}) \\
6 \text { weeks }\end{array}$ & $\begin{array}{l}\text { Fresh root } \\
\text { weight }(\mathrm{g}) \\
12 \text { weeks }\end{array}$ & $\begin{array}{c}\text { Dry root } \\
\text { weight }(\mathrm{g}) \\
6 \text { weeks }\end{array}$ & $\begin{array}{l}\text { Dry root } \\
\text { weight }(\mathrm{g}) \\
12 \text { weeks }\end{array}$ & $\begin{array}{c}\text { Fresh shoot } \\
\text { weight }(\mathrm{g}) \\
6 \text { weeks }\end{array}$ & $\begin{array}{c}\text { Fresh shoot } \\
\text { weight }(\mathrm{g}) \\
12 \text { weeks }\end{array}$ & $\begin{array}{l}\text { Dry shoot } \\
\text { weight }(\mathrm{g}) \\
6 \text { weeks }\end{array}$ & $\begin{array}{c}\text { Dry shoot } \\
\text { weight }(\mathrm{g}) \\
12 \text { weeks }\end{array}$ \\
\hline Mon & 0 & $5.58^{\mathrm{a} *}$ & $6.32^{\mathrm{a}}$ & $1.11^{\mathrm{a}}$ & $1.69^{\mathrm{a}}$ & $50.10^{\mathrm{a}}$ & $53.78^{\mathrm{a}}$ & $5.05^{\mathrm{a}}$ & $7.91^{\mathrm{a}}$ \\
\hline SA & 0 & $7.19^{\mathrm{a}}$ & $6.06^{\mathrm{a}}$ & $1.82^{\mathrm{a}}$ & $2.34^{\mathrm{a}}$ & $45.70^{\mathrm{a}}$ & $55.69^{\mathrm{a}}$ & $5.34^{\mathrm{a}}$ & $7.69^{\mathrm{a}}$ \\
\hline Sam & 0 & $6.82^{\mathrm{a}}$ & $6.40^{\mathrm{a}}$ & $0.94^{\mathrm{a}}$ & $3.91^{\mathrm{a}}$ & $43.30^{\mathrm{a}}$ & $42.30^{\mathrm{a}}$ & $7.09^{\mathrm{a}}$ & $8.69^{a}$ \\
\hline SM & 0 & $13.70^{\mathrm{a}}$ & $9.40^{\mathrm{a}}$ & $4.57^{\mathrm{a}}$ & $3.68^{\mathrm{a}}$ & $40.60^{\mathrm{a}}$ & $52.16^{\mathrm{a}}$ & $11.09^{\mathrm{a}}$ & $6.21^{\mathrm{a}}$ \\
\hline Mon & 500 & $8.12^{\mathrm{a}}$ & $4.34^{\mathrm{a}}$ & $2.13^{\mathrm{a}}$ & $2.55^{\mathrm{a}}$ & $48.80^{\mathrm{a}}$ & $57.73^{\mathrm{a}}$ & $6.16^{\mathrm{a}}$ & $7.40^{\mathrm{a}}$ \\
\hline SA & 500 & $9.21^{\mathrm{a}}$ & $8.62^{\mathrm{a}}$ & $2.64^{\mathrm{a}}$ & $2.26^{\mathrm{a}}$ & $48.80^{\mathrm{a}}$ & $55.99^{\mathrm{a}}$ & $6.96^{\mathrm{a}}$ & $7.05^{\mathrm{a}}$ \\
\hline Sam & 500 & $5.23^{\mathrm{a}}$ & $5.36^{\mathrm{a}}$ & $1.21^{\mathrm{a}}$ & $4.17^{\mathrm{a}}$ & $47.40^{\mathrm{a}}$ & $34.62^{\mathrm{a}}$ & $6.18^{\mathrm{a}}$ & $6.82^{\mathrm{a}}$ \\
\hline $\mathrm{SM}$ & 500 & $12.20^{\mathrm{a}}$ & $12.85^{\mathrm{a}}$ & $4.38^{\mathrm{a}}$ & $3.92^{\mathrm{a}}$ & $62.00^{\mathrm{a}}$ & $51.32^{\mathrm{a}}$ & $6.73^{\mathrm{a}}$ & $6.75^{\mathrm{a}}$ \\
\hline Mon & 1000 & $3.28^{\mathrm{a}}$ & $7.13^{\mathrm{a}}$ & $1.36^{\mathrm{a}}$ & $1.94^{\mathrm{a}}$ & $37.70^{\mathrm{a}}$ & $42.94^{\mathrm{a}}$ & $9.56^{\mathrm{a}}$ & $9.12^{\mathrm{a}}$ \\
\hline SA & 1000 & $15.65^{\mathrm{a}}$ & $13.21^{\mathrm{a}}$ & $3.48^{\mathrm{a}}$ & $2.78^{\mathrm{a}}$ & $46.70^{\mathrm{a}}$ & $45.62^{\mathrm{a}}$ & $7.49^{\mathrm{a}}$ & $4.91^{\mathrm{a}}$ \\
\hline Sam & 1000 & $3.08^{\mathrm{a}}$ & $10.97^{\mathrm{a}}$ & $0.73^{\mathrm{a}}$ & $3.21^{\mathrm{a}}$ & $26.20^{\mathrm{a}}$ & $34.07^{\mathrm{a}}$ & $10.29^{\mathrm{a}}$ & $7.78^{\mathrm{a}}$ \\
\hline SM & 1000 & $15.19^{\mathrm{a}}$ & $15.24^{\mathrm{a}}$ & $5.13^{\mathrm{a}}$ & $3.10^{\mathrm{a}}$ & $36.80^{\mathrm{a}}$ & $43.68^{\mathrm{a}}$ & $7.18^{\mathrm{a}}$ & $8.79^{\mathrm{a}}$ \\
\hline Mon & 5000 & $7.50^{\mathrm{a}}$ & $10.08^{\mathrm{a}}$ & $1.94^{\mathrm{a}}$ & $2.43^{\mathrm{a}}$ & $50.70^{\mathrm{a}}$ & $38.73^{\mathrm{a}}$ & $7.28^{\mathrm{a}}$ & $7.81^{\mathrm{a}}$ \\
\hline SA & 5000 & $16.52^{\mathrm{a}}$ & $15.70^{\mathrm{a}}$ & $11.46^{\mathrm{a}}$ & $4.47^{\mathrm{a}}$ & $54.40^{\mathrm{a}}$ & $52.32^{\mathrm{a}}$ & $8.08^{\mathrm{a}}$ & $7.14^{\mathrm{a}}$ \\
\hline Sam & 5000 & $8.68^{\mathrm{a}}$ & $15.12^{\mathrm{a}}$ & $1.31^{\mathrm{a}}$ & $2.72^{\mathrm{a}}$ & $49.20^{\mathrm{a}}$ & $46.15^{\mathrm{a}}$ & $4.54^{\mathrm{a}}$ & $6.75^{\mathrm{a}}$ \\
\hline SM & 5000 & $12.60^{\mathrm{a}}$ & $15.26^{\mathrm{a}}$ & $6.56^{\mathrm{a}}$ & $3.59^{\mathrm{a}}$ & $45.70^{\mathrm{a}}$ & $41.58^{\mathrm{a}}$ & $8.71^{\mathrm{a}}$ & $7.29^{\mathrm{a}}$ \\
\hline
\end{tabular}

${ }^{*}$ Means having different letters in a column differed significantly $(P \leq 0.05)$.

nematode, leading to the death of nematodes at the late $\mathrm{J} 2$ stage, rather than the average 12 hours postinfection response [26].

Wehner et al. [41] recounted 12 weeks postinoculation nematode, counts as the best option for inferring the response of rootstocks, as compared with six weeks nematode counts. Nematodes cause severe damage depending on their population densities, host species, temperature, and the period of incubation, to allow significant differentiation between resistant and susceptible rootstocks. A remarkable increase in nematode damage, along with reproduction, was observed 12 weeks after transplanting in both trials in $S$. aethiopicum. However, some rootstocks (Samrudhi F1, Mongal F1, and S. macrocarpon) suppressed nematode activities, indicating the existence of genetic variability among the rootstocks tested. In a previous study, Rahman et al. [42] observed the response of S. torvum and S. sisymbriifolium as resistant to RKNs. Similarly, Dhivya et al. [28] described S. torvum and S. aethiopicum as poor hosts of RKNs, whereas the former was found tolerant by Ioannou [25]. In our study, S. aethiopicum could be classified as tolerant to RKNs, although had high root gall development $(\mathrm{GS}=2.17-5.17)$, with increased reproduction $(\mathrm{Rf}=1.58-$ 2.37), the severest symptoms were observed during the dry season. This response could probably be due to predominant elevated soil temperatures, leading to the permanent breakdown of nematode resistance $M i$ gene [43, 44].

Unlike the resistance found in Samrudhi F1 $(\mathrm{GS}=0.33-0.67$ and $\mathrm{Rf}=0.36-0.57), S$. macrocarpon and Mongal F1 were found promising because of their potential in reducing nematode damage $(\mathrm{GS}=0.67-1.33$ and $1.67-$ 3.00 , respectively). Based on nematode reproduction on a host, their response could best be described as tolerant because population levels of nematodes recovered were still high $(\mathrm{Rf}>1)$ in field experiments, but below 1 in pot experiments. Similarly, Lopez-Perez et al. [45] documented a tolerant response in resistant $M i$ gene-bearing rootstock Beaufort, for supporting RKN reproduction, with higher yields compared with a susceptible genotype (Blitz). In another test, where 33 tomato genotypes were assessed by Jaiteh et al. [29], Mongal T-11 and Mongal F1 number 5 emerged resistant $(\mathrm{GS}=3.25$ and $\mathrm{Rf}=0.71)$ and susceptible $(\mathrm{GS}=7.25$ and $\mathrm{Rf}=2.47)$, respectively. Tzortzakakis et al. [46] also reported S. macrocarpon's susceptibility to RKNs. However, in the current study, the observed tolerance in $S$. macrocarpon and Mongal F1 might be due to inactivation of the $M i$ gene arising from mutation, if present in the genotypes [45], or the possession of other genes (horizontal resistance) rather than $M i$ gene. Solanum macrocarpon's hardy roots makes penetration relatively difficult for nematodes compared with tomato roots. Alternatively, $M i$ gene dosage effect may account for increased nematode reproduction in tolerant $M i$ heterozygous individuals than in homozygous individuals $[47,48]$.

Apart from reducing nematode damage, resistant rootstocks are cultivated to help improve plant fitness and yield. Consequently, growth and yield performance of the test rootstocks was evaluated in the study in infected and controlled environments, to various inocula levels of RKN in pot experiments. The absence of significant differences in the rootstocks in relation to the growth parameters (fresh and dry shoot and root weights) shows the tolerance levels of the various rootstocks to the RKN, irrespective of the inocula level in the pot trials. Within the field experiments, significant differences in plant girth, height, and chlorophyll content were obtained among the tested rootstocks. These observed differences showed that although the rootstocks belonged to the same Solanum genus, these had (3) different species origins. Among the three tomato rootstocks, Mongal F1, however, presented a more robust growth after transplanting. 


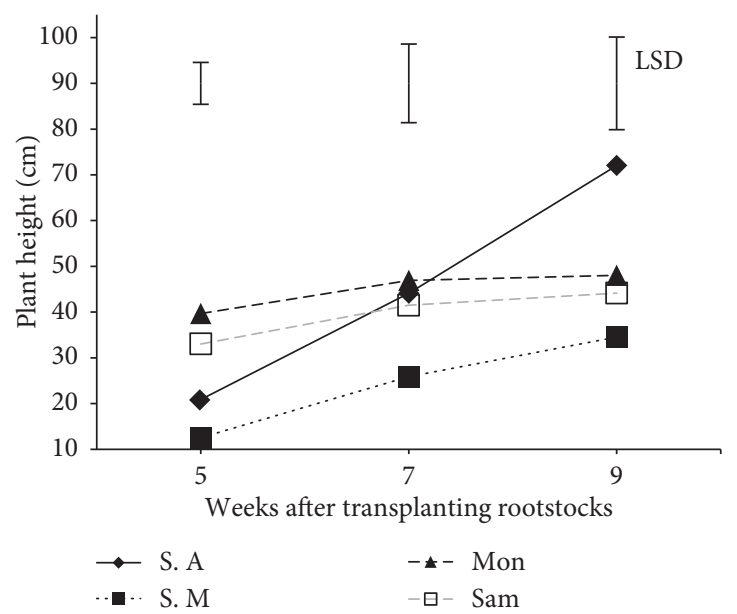

(a1)

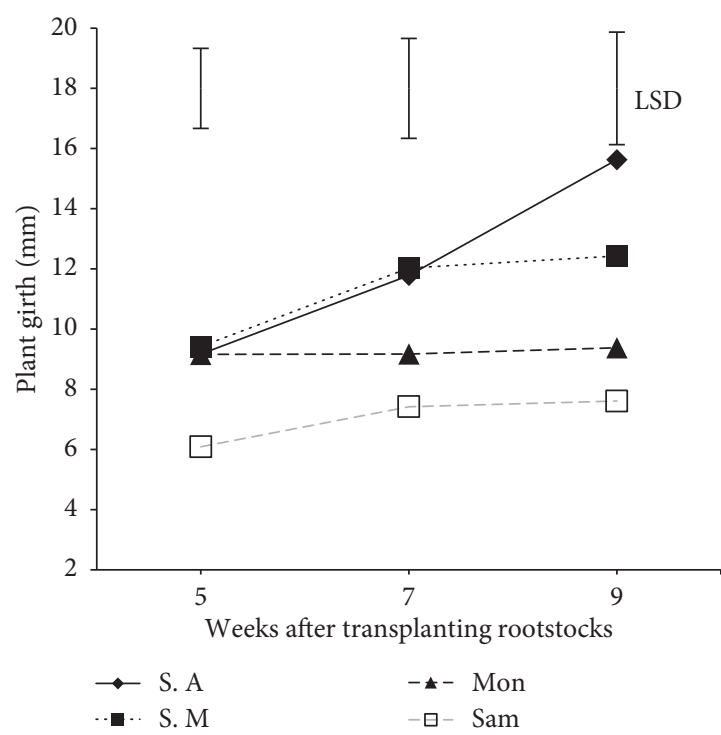

(b1)

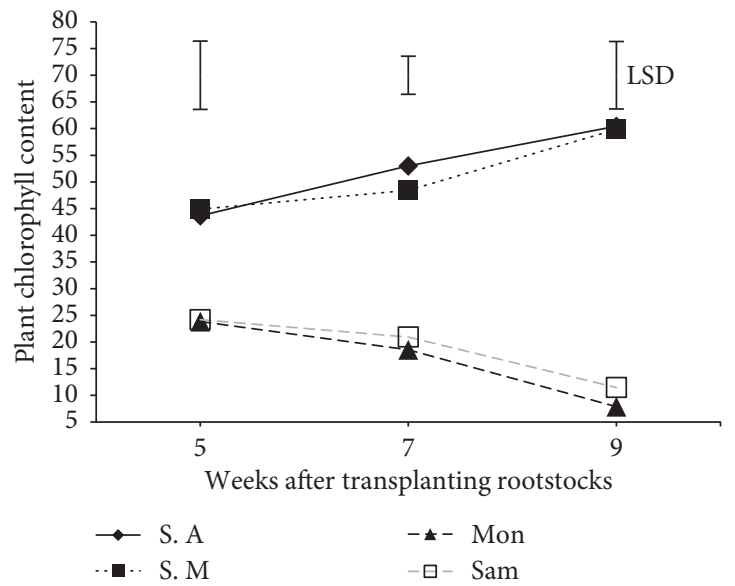

$(\mathrm{c} 1)$

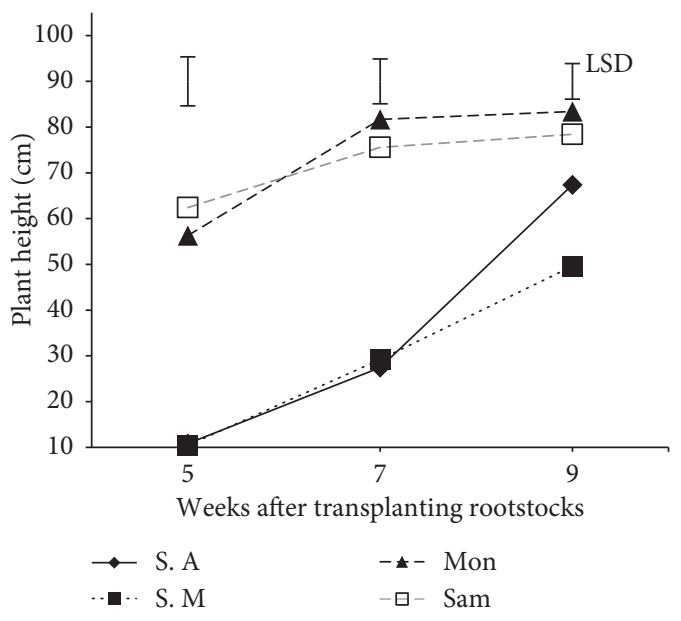

(a2)

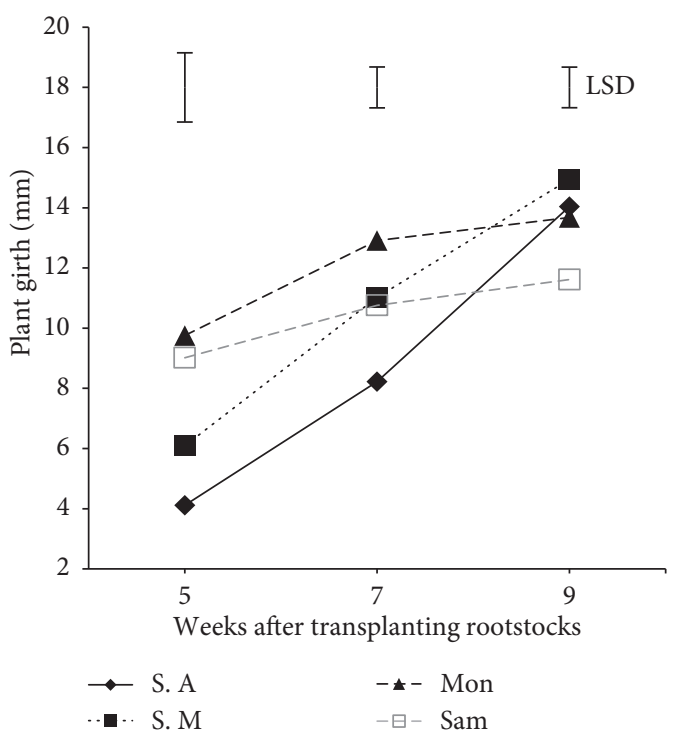

(b2)

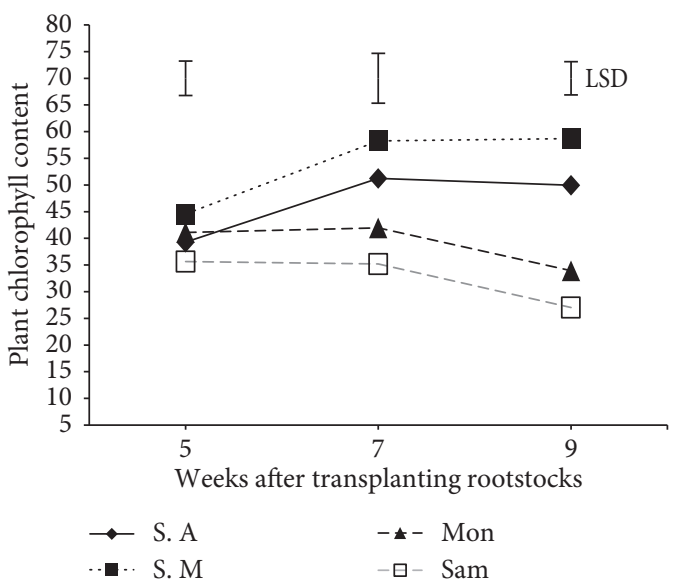

(c2)

Figure 1: Growth parameters of rootstocks to RKN infection at five, seven, and nine weeks after transplanting rootstocks. (a) The mean plant height, (b) the mean plant girth (c) the mean chlorophyll content in 2015 (1) and 2016 (2). Rootstocks: Sam=Samrudhi F1; Mon = Mongal F1; S. M = S. macrocarpon; S. A = S. aethiopicum. Data were analyzed with two-way ANOVA and significant means separated with the least significant difference (LSD) test. LSD bars represent the least significant difference at $P \leq 0.05$. 
TABLE 4: Mean yield parameters of the rootstocks after RKN infestation in 2015 (year 1) and 2016 (year 2).

\begin{tabular}{|c|c|c|c|c|c|}
\hline Treatment & $\begin{array}{c}\text { Days to } 50 \% \\
\text { flowering }\end{array}$ & $\begin{array}{l}\text { Number of } \\
\text { fruits/plant }\end{array}$ & Fruit yield/plant (g) & $\begin{array}{c}\text { Fruit yield } \\
(\mathrm{kg} / \mathrm{ha})\end{array}$ & $\begin{array}{c}\text { Mean fruit } \\
\text { weight/plant (g) }\end{array}$ \\
\hline \multicolumn{6}{|c|}{ Year 1 (dry season) } \\
\hline Sam & $28.00^{\mathrm{a}}$ & $2.33^{\mathrm{a}}$ & $23.70^{\mathrm{a}}$ & $2961^{a}$ & $8.89^{\mathrm{a}}$ \\
\hline Mon & $27.00^{\mathrm{a}}$ & $5.00^{\mathrm{ab}}$ & $44.62^{\mathrm{a}}$ & $5581^{\mathrm{a}}$ & $7.43^{\mathrm{a}}$ \\
\hline S. M & $39.00^{\mathrm{b}}$ & $10.33^{\mathrm{bc}}$ & $227.50^{c}$ & $28442^{\mathrm{b}}$ & $22.74^{\mathrm{b}}$ \\
\hline S. A & $51.00^{\mathrm{c}}$ & $12.00^{\mathrm{c}}$ & $147.61^{\mathrm{b}}$ & $18448^{\mathrm{ab}}$ & $12.30^{\mathrm{b}}$ \\
\hline \multicolumn{6}{|c|}{ Year 2 (rainy season) } \\
\hline Sam & $27.00^{\mathrm{b}}$ & $13.00^{\mathrm{ab}}$ & $870.30^{\mathrm{b}}$ & $27196.87^{\mathrm{b}}$ & $66.95^{\mathrm{c}}$ \\
\hline Mon & $29.00^{\mathrm{b}}$ & $20.00^{\mathrm{b}}$ & $1236.60^{\mathrm{c}}$ & $38643.75^{c}$ & $61.82^{\mathrm{c}}$ \\
\hline S. M & $41.00^{\mathrm{c}}$ & $9.00^{\mathrm{a}}$ & $339.10^{\mathrm{a}}$ & $10596.88^{\mathrm{a}}$ & $37.68^{\mathrm{b}}$ \\
\hline S. A & $58.00^{\mathrm{d}}$ & $19.00^{\mathrm{b}}$ & $204.40^{\mathrm{a}}$ & $6387.50^{\mathrm{a}}$ & $10.75^{\mathrm{a}}$ \\
\hline
\end{tabular}

Means having different letters in a column differ significantly $(P \leq 0.05)$. Rootstocks: Sam = Samrudhi F1; Mon = Mongal F1;. M =S. macrocarpon; S. A = S. aethiopicum.

TABle 5: Mean fresh and dry weights of shoot and roots of rootstocks after 12 weeks of root-knot nematode infestation.

\begin{tabular}{|c|c|c|c|c|}
\hline Treatment & Fresh shoot weight $(\mathrm{g})$ & Dry shoot weight $(\mathrm{g})$ & Fresh root weight $(\mathrm{g})$ & Dry root weight $(\mathrm{g})$ \\
\hline \multicolumn{5}{|c|}{ Year 1 (dry season) } \\
\hline Sam & $40.60^{\mathrm{a}}$ & $8.74^{\mathrm{a}}$ & $3.74^{\mathrm{a}}$ & $0.96^{\mathrm{a}}$ \\
\hline Mon & $53.70^{\mathrm{a}}$ & $11.13^{\mathrm{a}}$ & $5.17^{\mathrm{ab}}$ & $1.42^{\mathrm{ab}}$ \\
\hline S. M & $159.10^{\mathrm{ab}}$ & $33.78^{\mathrm{ab}}$ & $14.05^{\mathrm{b}}$ & $5.20^{\mathrm{b}}$ \\
\hline S. A & $331.40^{\mathrm{b}}$ & $76.73^{\mathrm{b}}$ & $39.72^{c}$ & $16.81^{\mathrm{c}}$ \\
\hline \multicolumn{5}{|c|}{ Year 2 (rainy season) } \\
\hline Sam & $257.74^{\mathrm{a}}$ & $47.74^{\mathrm{a}}$ & $25.13^{\mathrm{a}}$ & $10.65^{\mathrm{a}}$ \\
\hline Mon & $325.28^{\mathrm{ab}}$ & $65.02^{\mathrm{a}}$ & $27.09^{\mathrm{a}}$ & $12.09^{\mathrm{a}}$ \\
\hline S. M & $357.39^{\mathrm{b}}$ & $62.14^{\mathrm{a}}$ & $24.74^{\mathrm{a}}$ & $12.67^{\mathrm{a}}$ \\
\hline S. A & $255.44^{\mathrm{a}}$ & $63.51^{\mathrm{a}}$ & $32.31^{\mathrm{a}}$ & $19.43^{\mathrm{b}}$ \\
\hline
\end{tabular}

Means having different letters in a column differ significantly $(P \leq 0.05)$. Rootstocks: Sam = Samrudhi F1; Mon = Mongal F1; S. M=S. macrocarpon; S.A = S. aethiopicum.

The plants were tall with thick stems and appeared dark green. Compared with Samrudhi F1, the plants stood more erect (even at flowering) with soft stem tissues that easily break upon fruit bearing (weight). The resistant response of host crops to RKNs is well known to correspond to increased yield $[24,42,45]$. The fruit yield of the tolerant rootstock (Mongal F1) was significantly increased, compared with the resistant Samrudhi F1. This suggests Mongal F1's efficiency in converting resources into fitness and in bearing of fruit rather than controlling nematodes. Restif and Koella [49] detected the distribution of tolerant plant resources towards fitness, unlike in resistant plants where this is aimed at reducing pathogen infection. Within Samrudhi F1 genotypes, appreciable yields would be obtained in addition to suppressed nematode population, making it possible for the cultivation of susceptible crops in subsequent years [50].

\section{Conclusion}

Our investigation showed tomato Samrudhi F1 as resistant, whereas tomato $S$. macrocarpon, S. aethiopicum, and Mongal F1 were tolerant to RKNs. These rootstocks, can serve as tomato rootstocks, in breeding programs targeted at nematode management. Tolerance mechanisms of plants against nematodes are less understood and should be further investigated.

\section{Data Availability}

The data used to support the findings of this study are included within the article.

\section{Conflicts of Interest}

The authors declare that there are no conflicts of interest regarding the publication of this article.

\section{Acknowledgments}

The authors are grateful to the University of Ghana Research Fund (UGRF), with a grant to NA and STN in response to the 7 th call for proposals.

\section{References}

[1] R. Srinivasan, Safer Tomato Production Techniques: a Field Guide for Soil Fertility and Pest Management, Vol. 10, AVRDC-World Vegetable Center, Tainan, Taiwan, 2010.

[2] J. O. Olaniyi, W. B. Akanbi, T. A. Adejumo, and O. G. Ak, "Growth, fruit yield and nutritional quality of tomato varieties," African Journal of Food Science, vol. 4, no. 6, pp. $398-402,2010$. 
[3] J. Jaramillo, V. Rodriguez, M. Guzman, M. Zapata, and T. Rengifo, Technical Manual: Good Agricultural Practices in the Production of Tomato under Protected Conditions, FAO, Rome, Italy, 2007.

[4] B. B. Freeman and K. Reimers, "Tomato consumption and health: emerging benefits," American Journal of Lifestyle Medicine, vol. 5, no. 2, pp. 182-191, 2011.

[5] D. Bhowmik, K. S. Kumar, S. Paswan, and S. Srivastava, "Tomato-a natural medicine and its health benefits," Journal of Pharmacognosy and Phytochemistry, vol. 1, no. 1, pp. 33-43, 2012.

[6] B. van Dam, Barbara, M. D. Goffau, J. van Lidt de Jeude, and S. Naika, Cultivation of Tomato: Production, Processing and Marketing, Agrodok, Dififrafi, Wageningen, Netherlands, 2005.

[7] Food and Agriculture Organization of the United Nations, Statistics Division (FAOSTAT), Food and Agriculture Data, July 2017, http://www.fao.org/faostat/en/\#data/QC.

[8] D. Horna, M. Smale, and J. Falck-Zepeda, "Assessing the potential economic impact of genetically modified crops in Ghana: Tomato, garden egg, cabbage and cassava," Program for Biosafety Systems Report, IFPRI, International Food Policy Research Institute, Washington, D.C., USA, 2006.

[9] P. Abad, B. Favery, M. N. Rosso, and P. Castagnone-Sereno, "Root-knot nematode parasitism and host response: molecular basis of a sophisticated interaction," Molecular Plant Pathology, vol. 4, no. 4, pp. 217-224, 2003.

[10] P. Castagnone-Sereno, "Genetic variability and adaptive evolution in parthenogenetic root-knot nematodes," Heredity, vol. 96, no. 4, pp. 282-289, 2006.

[11] J. N. Sasser, Plant-Parasitic Nematodes: the Farmer's Hidden Enemy, North Carolina State University Graphics, Raleigh, NC, USA, 1989.

[12] D. J. Chitwood, Nematicide, USDA-ARS, Beltsville, MD, USA, January 2016, http://www.ars.usda.gov/SP2UserFiles/person/ 990/Chitwood2003NematicideReview.pdf.

[13] M. Keren-Zur, J. Antonov, A. Bercovitz et al., "Bacillus firmus formulations for the safe control of root-knot nematodes," in Proceedings of an International BCPC Conference on Pests and Diseases, vol. 1, pp. 47-52, British Crop Protection Council, Brighton, UK, November 2000.

[14] R. A. Sikora and E. Fernandez, "Nematode parasites of vegetables," in Plant Parasitic Nematodes in Subtropical and Tropical Agriculture, pp. 319-392, CABI Publishing, Wallingford, UK, 2nd edition, 2005.

[15] P. G. Addoh, "The root-knot nematode problem in Ghana: host and non-host plants of Meloidogyne species," Ghana Journal of Agricultural Science, vol. 3, no. 1, pp. 3-12, 1970.

[16] O. B. Hemeng, "Efficacy of selected nematicides for the control of root knot nematode, Meloidogyne spp. on tomato in Ghana," Ghana Journal of Agricultural Science, vol. 13, pp. 37-40, 1981.

[17] G. De Lannoy, Vegetables: Crop Production in Tropical Africa, DGIC, Brussels, Belgium, 2001.

[18] A. U. Charchar, J. M. Gonzaga, V. Giordano, L. D. Boiteuy, and L. S. Reis, "Reaction of tomato cultivars to infection by a mixed population of $M$. incognita race and $M$. javanica in the field," Nematologia Brasileira, vol. 27, pp. 49-54, 2003.

[19] S. R. Gowen, "Chemical control of nematodes: efficiency and side-effects," FAO Plant Production and Protection Paper, January 2016, http://www.fao.org/docrep/v9978e/v9978e08. htm.

[20] D. Nordmeyer, "The search for novel nematicidal compounds," in Nematology from Molecules to Ecosystems, pp. 281-293, European Society of Nematologists, Invergowrie, Dundee, Scotland, 1992.

[21] S. Khanzada, M. M. Jiskani, S. R. Khanzada et al., "Response of some tomato cultivars against root-knot nematode, Meloidogyne incognita (Kofoid \& White) Chitwood," Journal of Animal and Plant Sciences, vol. 22, no. 4, pp. 1076-1080, 2012.

[22] I. L. P. Da Conceição, M. C. V. Dos Santos, I. M. D. O. Abrantes, and M. S. N. D. Santos, "Using RAPD markers to analyze genetic diversity in Portuguese potato cyst nematode populations," Nematology, vol. 5, no. 1, pp. 137143, 2003.

[23] M. Luc, R. A. Sikora, and J. Bridge, Plant Parasitic Nematodes in Subtropical and Tropical Agriculture, CABI Publishing, Oxfordshire, England, 2nd edition, 2005.

[24] B. P. Corbett, L. Jia, R. J. Sayler, L. M. Arevalo-Soliz, and F. Goggin, "The effects of root-knot nematode infection and mi-mediated nematode resistance in tomato on plant fitness," Journal of Nematology, vol. 43, no. 2, pp. 82-89, 2011.

[25] N. Ioannou, "Integrating soil solarization with grafting on resistant rootstocks for management of soil-borne pathogens of eggplant," Journal of Horticultural Science and Biotechnology, vol. 76, no. 4, pp. 396-401, 2001.

[26] S. B. Milligan, J. Bodeau, J. Yaghoobi, I. Kaloshian, P. Zabel, and V.M. Williamson, "The root-knot nematode resistance gene $\mathrm{Mi}$ from tomato is a member of the leucine zipper, nucleotide binding, leucine-rich repeat family of plant genes," Plant Cell, vol. 10, no. 8, pp. 1307-1319, 1998.

[27] G. Nombela, V. M. Williamson, and M. Muniz, "The rootknot nematode resistance gene Mi-1.2 of tomato is responsible for resistance against the whitefly Bemisiatabaci," Molecular Plant-Microbe Interactions, vol. 16, no. 7, pp. 645-649, 2003.

[28] R. Dhivya, A. Sadasakthi, and M. Sivakumar, "Response of wild solanum rootstocks to root-knot nematode (Meloidogyne incognita Kofoid and White)," International Journal of Plant Sciences, vol. 9, no. 1, pp. 117-122, 2014.

[29] F. Jaiteh, C. Kwoseh, and R. Akromah, "Evaluation of tomato genotypes for resistance to root-knot nematodes," African Crop Science Journal, vol. 20, no. 1, pp. 41-49, 2012.

[30] F. J. Louws, C. L. Rivard, and C. Kubota, "Grafting fruiting vegetables to manage soil borne pathogens, foliar pathogens, arthropods and weeds," Scientia Horticulturae, vol. 127, no. 2, pp. 127-146, 2010.

[31] C. A. Clark and J. W. Moyer, Compendium of Sweet Potato Diseases, American Phyto-Pathological Society, St. Paul, MN, USA, 1988.

[32] R. S. Hussey and K. R. Barker, "A comparison of methods of collecting inocula of Meloidogyne spp., including a new technique," Plant Disease Report, vol. 57, pp. 1025-1028, 1973.

[33] W. R. Jenkins, "A rapid centrifugal-flotation technique for separating nematodes from soil," Plant Disease Reporter, vol. 48, no. 9, 1964.

[34] J. Bridge and S. L. J. Page, "Estimation of root-knot nematode infestation levels on roots using a rating chart," International Journal of Pest Management, vol. 26, no. 3, pp. 296-298, 1980.

[35] Z. Devran and I. H. Elekçioglu, "The screening of $F_{2}$ plants for the root-knot nematode resistance gene, Mi by PCR in Tomato," Turkish Journal of Agriculture and Forestry, vol. 28, no. 4, pp. 253-257, 2004.

[36] J. N. Sasser, C. C. Carter, and K. M. Hartman, Standardization of Host Suitability Studies and Reporting of Resistance to RootKnot Nematodes, A Co-Operative Publication of North Carolina State University, Department of Plant Pathology and USAID, Raleigh, NC, USA, 1984. 
[37] VSN International Ltd., Genstat 12th Edition for Windows, VSN Int. Ltd., Oxford, UK, 2009.

[38] G. Liébanas and P. Castillo, "Host suitability of some crucifers for root-knot nematodes in southern Spain," Nematology, vol. 6, no. 1, pp. 125-128, 2004.

[39] G. Karssen and M. Moens, "Root-knot nematodes," in Plant Nematology, R. N. Perry and M. Moens, Eds., pp. 59-90, CAB International, Wallingford, UK, 2006.

[40] M. Sobczak, A. Avrova, J. Jupowicz, M. S. Phillips, K. Ernst, and A. Kumar, "Characterization of susceptibility and resistance responses to potato cyst nematode (Globodera spp.) infection to tomato lines in the absence and presence of the broad-spectrum nematode resistance Hero-gene," Molecular Plant-Microbe Interactions, vol. 18, no. 2, pp. 158-168, 2005.

[41] T. C. Wehner, S. A. Walters, and K. R. Barker, "Resistance to root-knot nematodes in cucumber and horned cucumber," Journal of Nematology, vol. 23, no. 4S, p. 611, 1991.

[42] M. A. Rahman, M. A. Rashid, M. A. Salam, M. A. T. Masud, A. S. H. Masum, and M. M. Hossain, "Performance of some grafted eggplant genotypes on wild Solanum root stocks against root-knot nematode," Journal of Biological Sciences, vol. 2, no. 7, pp. 446-448, 2002.

[43] S. Verdejo-Lucas, M. Blanco, L. Cortada, and F. J. Sorribas, "Resistance of tomato rootstocks to Meloidogyne arenaria and Meloidogyne javanica under intermittent elevated soil temperatures above $28^{\circ}$ C," Crop Protection, vol. 46, pp. 57-62, 2013.

[44] Z. Devran, M. A. Sogut, and N. Mutlu, "Response of tomato rootstocks with the Mi resistance gene to Meloidogyne incognita race 2 at different soil temperatures," Phytopathologia Mediterranea, vol. 49, no. 1, pp. 11-17, 2010.

[45] J. A. Lopez-Perez, M. L. Strange, I. Kaloshian, and A.T. Ploeg, "Differential response of Mi gene-resistant tomato rootstocks to root-knot nematodes (Meloidogyne incognita)," Crop Protection, vol. 25, no. 4, pp. 382-388, 2006.

[46] E. A. Tzortzakakis, F. A. Bletsos, and A. D. Avgelis, "Evaluation of Solanum rootstock accessions for control of root-knot nematodes and tobamoviruses," Journal of Plant Diseases and Protection, vol. 113, no. 4, pp. 188-189, 2006.

[47] E. A. Tzortzakakis, D. L. Trudgill, and M. S. Phillips, "Evidence for a dosage effect of the Mi gene on partially virulent isolates of Meloidogyne javanica," Journal of Nematology, vol. 30, no. 1, pp. 76-80, 1998.

[48] M. Jacquet, M. Bongiovanni, M. Martinez, P. Verschave, E. Wajnberg, and P. Castagnone-Sereno, "Variation in resistance to the root-knot nematode Meloidogyne incognita in tomato genotypes bearing the Mi gene," Plant Pathology, vol. 54, no. 2, pp. 93-99, 2005.

[49] O. Restif and J. C. Koella, "Concurrent evolution of resistance and tolerance to pathogens," American Naturalist, vol. 164, no. 4, pp. E90-E102, 2004.

[50] C. Ornat, S. Verdejo-Lucas, and F. J. Sorribas, "Effect of the previous crop on population densities of Meloidogyne javanica and yield of cucumber," Nematropica, vol. 27, no. 1, pp. 85-90, 1997. 


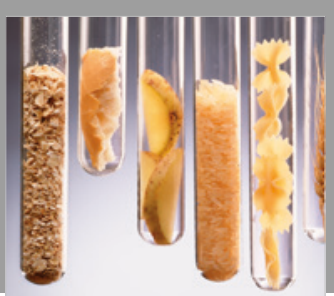

International Journal of Food Science

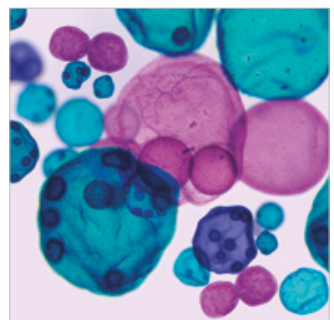

International Journal of Microbiology
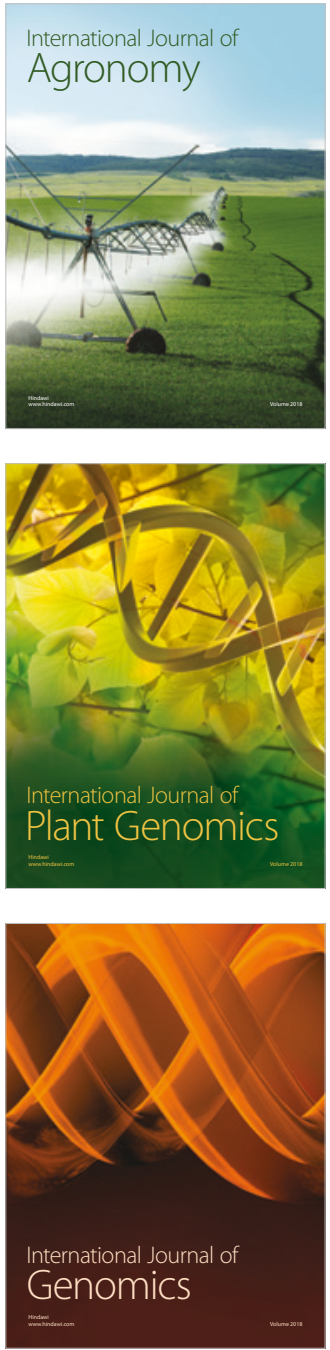

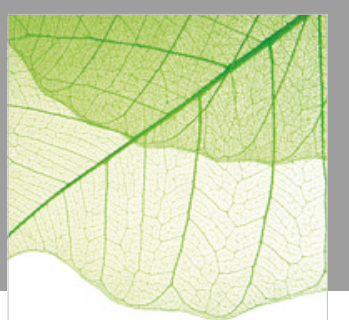

Journal of Botany
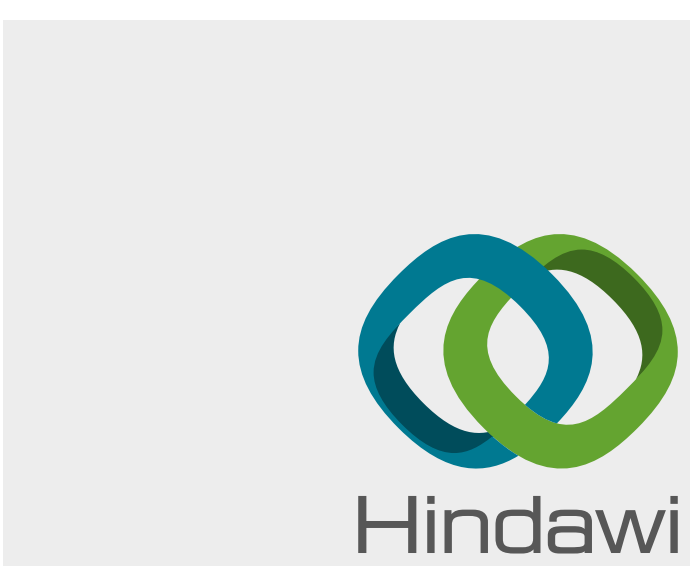

Submit your manuscripts at

www.hindawi.com
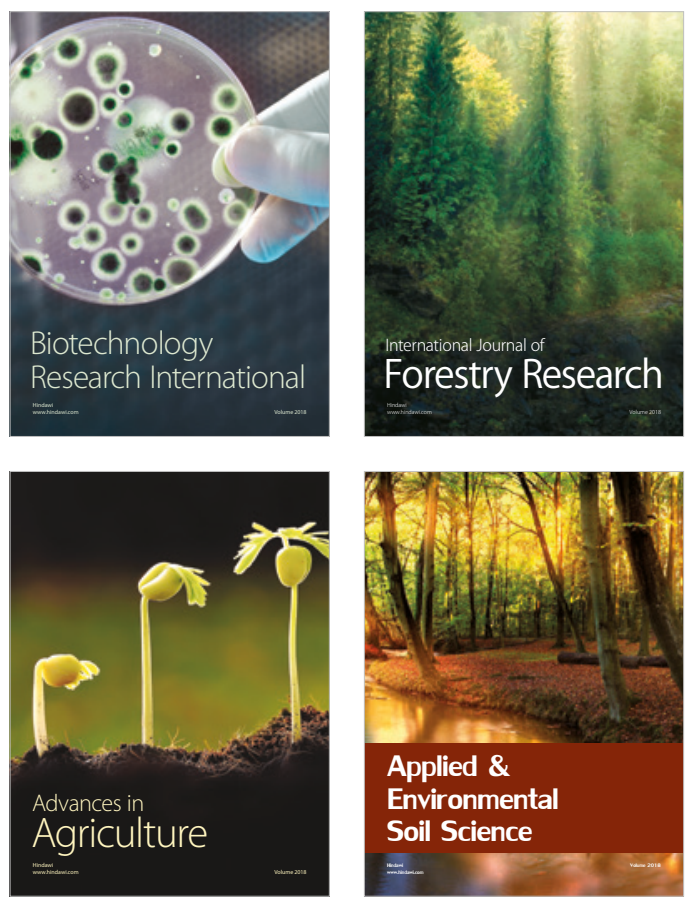

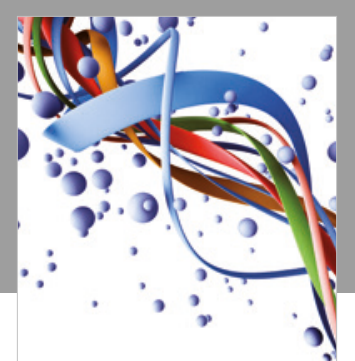

Scientifica

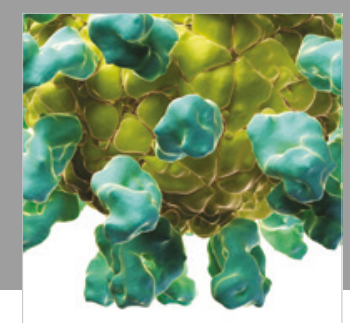

Veterinary Medicine International

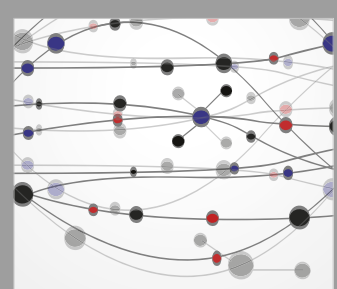

The Scientific World Journal
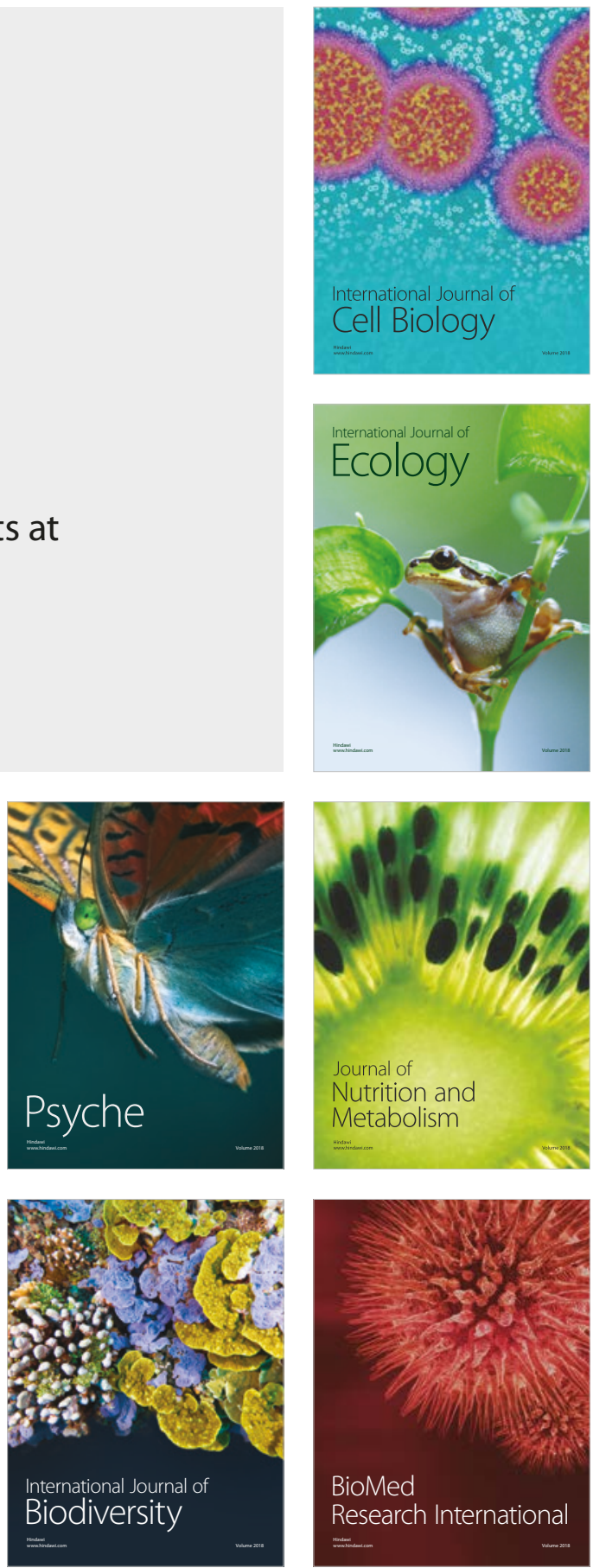